\title{
COVID-19 Pandemic is not Apocalypse, is Strong Warning
}

\begin{abstract}
Athari SS*
Department of Immunology, School of Medicine, Zanjan University of medical sciences, Iran
\end{abstract}

*Corresponding author: Seyyed Shamsadin Athati, Department of Immunology, School of Medicine, Zanjan University of medical sciences, Zanjan, Iran; Email: SS.Athari@gmail.com

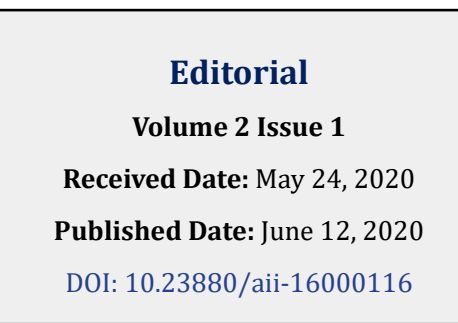

Editorial

Human health and security is important dimension of human life and are essential instruments to human survival, livelihood and dignity. Health and security are closely related and the health significance in achieving human security is evidenced by the fact. Natural disasters, such as earthquakes, tsunamis, hurricanes, volcano eruptions, drought, floods, landslides, forest fires, etc. all present major threats to human health and security. These disasters directly impact human life and often destroy biological, physical and social environments, but also have long-term effects on human security, health, well-being and survival [1]. One of the biggest threats to global health and security is COVID-19. SARS-CoV-2 belongs to the $\beta$-CoVs category and has round or elliptic and often pleomorphic form with approximately 60$140 \mathrm{~nm}$ diameter. It has 29891 nucleotides single-stranded RNA genome, which encoding 9860 amino acids [2]. The COVID-19 (SARS-CoV-2) pandemic has tremendously affected the world people. COVID-19 effects of the all human world health; change the life style and behavioral pattern. The hopefulness of the human being for an extraordinary scientific occurrence or who solves this terrible problem. To find a scientific solution, an integrated model of basic and clinical medicine is needed and immunological basis of lung stiffness should be applied as a novel pathway for drug discovery, vaccine generation and the application for managing the patients [3-5]. At now, all countries experience apocalypse as a result of a virus outbreak, terrible pandemic coronavirus (COVID-19) in century of 21 [6]. 2006 film by Mel GibsonI as immunologist know these approaches, but there are some other ultra-mind factors that should be attention. The main concept is that COVID-19 is not an Apocalypse now, but is very big alarm for all people of world.

The mathematics and physics relationship, the nature of reason, metaphysics, sciences, theories of the universe origin and the laws of nature; the possibility that the universe shows evidence of a deity and provide a few arguments for the existence of God. But human self-recognition is doomed to failure and belief to the biggest creator can be saved mankind. The Human should solve the toughest problems that face today. The human beings never have to fight for respect and human value in the respectful. There are millions of invisible connections between our bodies and minds that determine our future. Together, we can reveal the best picture to creating a better world. We do not know the life philosophy, because we never cannot read the God mind. Therefore, the God has been initiated the human project and this project will not be failed. Mahdi, hujjat Allah ibn Hasan also known as Imam Zaman (Time owner), is believed by Shia Twelver Muslims, an eschatological redeemer of Islam and the last Imam (Twelfth Imam) who will emerge with Jesus Christ in order to fulfil their mission of bringing peace and justice to the all of world. He is the victorious Imam of Shia and will restore the purity of the Faith, bring true and uncorrupted guidance to all human being, create an adequately just social order and make a world free from tyranny and wickedness. He is in the major occultation and will be returned in apocalypse $[7,8]$. On the other hand, these days, public opinion and global organizations have turned their attention to the coronavirus (COVID-19) and its widespread spread, NASA observed an asteroid, which could be the end point for the extinction of the human race! 52768) OR2 1998) is an asteroid on an eccentric orbit, and classified as a near-Earth object, potentially hazardous asteroid of the Amor group, with a diameter of 2 kilometers. On 29 April 2020, the asteroid passed at a distance of 6.3 million $\mathrm{km}$ from Earth. Any asteroid with a length of more than $1 \mathrm{~km}$ can be considered a global threat and destroy terrestrial life. The collision of these types of asteroids could lead to global destruction and even the possible collapse of human civilization. The main problem was that at that moment, not much could be done by humans (Figure 1). So, God warns on a very small (Nano-virus) to very large (asteroid) scale that human beings are incapable of repelling any danger and must rely on a global leadership in the shadow of morality (ethic) and divine teachings. 


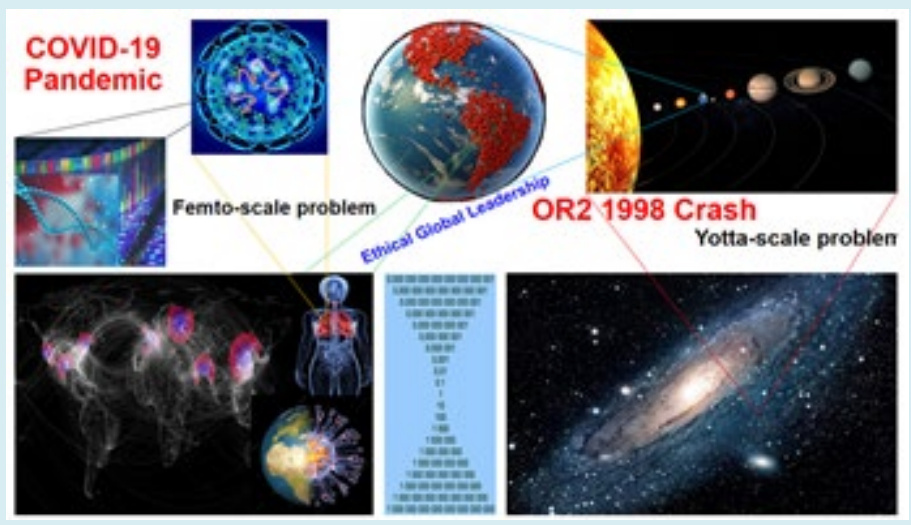

Figure 1: Global health and security has challenge from little than nano-scale (coronavirus pandemic) to bigger than gigascale) OR2 1998 asteroid crash to the earth), from electrons to the galaxies. Therefore, world needs ethical global leadership to have control and solution for unknown problems in the future.

\section{References}

1. Couplanda R (2017) Security, insecurity and health: Bulletin of the World Health Organization. World Health Organization 85: 181-184.

2. Chan JFW, Kok KH, Zhu Z, Chu H, To KKW, et al. (2020) Genomic characterization of the 2019 novel humanpathogenic coronavirus isolated from a patient with atypical pneumonia after visiting Wuhan. Emerg Microbes Infect 9(1): 221-236.

3. Minni A, Ralli M, Candelori F, Cialente F, Ercoli L, et al. (2020) Lessons Learned from COVID-19 Pandemic in Italy. Bosn J Basic Med Sci 20: 1-6.
4. Athari SS (2020) Quarantining at Home Controls COVID-19 Exposes, May Increase Asthma Mortality. J Immuno Allerg 1(3): 1-2

5. Laventhal N, Basak R, Dell ML, Diekema D, Elster N, et al. (2020) The Ethics of Creating a Resource Allocation Strategy During the COVID-19 Pandemic. Pediatrics 145(5): e20201243.

6. Dabbagh A (2020) COVID-19: Apocalypse Now? Journal of Cellular \& Molecular Anesthesia 5(1): 1-2.

7. Majlesi MB (1694) Bihar al-Anwar.

8. Rey Shahri MM (2016) Encyclopedia of Imam Mahdi based on Quran, Hadith 10. 